\title{
50 years of the Polish Physician-Writers Union
}

The present Polish Physician-Writers Union started first under the name of the Polish Medic-Writers Union (Unia Polskich Pisarzy Medyków - UPPM). It was established in Radziejowice, during a meeting taking place on October $6^{\text {th }}$ and $7^{\text {th }} 1967$. The founders of UPPM included presently well-known writers with significant literary achievements, such as: Jerzy Pomianowski, Stanisław Lem, Danuta Bieńkowska, Jerzy Lutowski, Stanislaw Sterkowicz. In a short time professors Julian Aleksandrowicz, Boleslaw Górnicki, Henryk Gaertner, Kazimierz Czyżewski, Witold J. Kapuścińs-

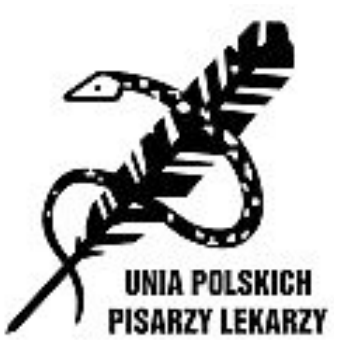
ki, Maciej Wit-Rzepecki joined UPPM.

UPPM developed quite rapidly, in spite of the censorship and control of the state and party authorities. In 1978 UPPM got a permission to publish its own "SPEKTRUM" almanac. The imposition of the martial law in 1981 led to the 3 year-long suspensionof UPPM activity. The organization was reestablished in 1985 taking the new name of the Polish Physician-Writers Union (Unia Polskich Pisarzy Lekarzy - UPPL). The management board of the revived UPPL drew anew statute for organization up, following the guidelines of the World Union of Medical Writers (Union Mondiale des Ecrivantes-Medecines - UMEM). UMEM itself was established in Lucerne, in 1968, a year later than UPPM. Yet the beginnings of UMEM stretch as far back as 1955, when European Federation of Physician-Writers (Fédération Internationale des Sociétés des Medecins Écrivains - FISEM) was started.

UPPM, and later UPPL, organized three international congresses of UMEM in Poland. The first, the XVIIIth UMEM Congress, took place in 1973 in Warsaw, under the heading: „Physician and Peace”. The XLIVth UMEM Congress was organized in 2000 in Łódź, its subjects being the role of the literature in the shaping of the physicians' attitudes and multicultural inspirations in the literature. The last UMEM meeting taking place in Poland was its LIVth Congress organized in 2010 in Płock under the title of „Ethics and Morality”.

UPPL currently comprises of 74 members - all graduates of Medical Universities (formerly known as Medical Academies). UPPL is financed solely from membership fees, the cost of all the meetings born in full by their participants.

Apart from the above mentioned „Spektrum” almanac editions, three editions of poetry "treasure chests” (each comprised of five A-6 format volumes) were published in years 1994-1996 by UPPL. These were, in later years, replaced by the UPPL Booklet series (with 36 published until present).

The former chairmen of the UPPM/UPPL were: Jerzy Pomianowski (1967-1969), Grzegorz Fedorowski (1970-1971), Jerzy Lutowski (1971-1976), Witold Kapuściński (1977-1978), Marcin Łyskanowski (1979-1983), Piotr Müldner-Nieckowski (1984-1989), Barbara Szeffer-Marcinkowska (1990-2002), Marek Pawlikowski (2003-2014). The present chairmen of UPPL, for the 2015-2018 term, is Waldemar Hładki.

UPPL organizes symposia, conferences, literary feasts, including the Warsaw Autumn of Poetry, organized together with the Polish Writers' (Związek Literatów Polskich - ZPL). Many members of the won prizes in the literary competitions and cooperate with publishing firms on permanent basis. The UPPL members create both poetry and prose of different fields - ranging from the non-fiction works to the belles-lettres. Some of them combine literature with photography and painting.

The jubilee Conference of UPPL, celebrating 50 years of UPPL existence, took place in Cracow, on October $6^{\text {th }}-8^{\text {th }} 2017$. This meeting gathered not only active UPPL members, but also a number of representatives of the world of science and culture, who consider themselves friends of UPPL. They were also joined by the people from the world of politics and medical self-government bodies.

The jubilee celebrations of the 50 years of UPPL establishment took place in the Manggha Museum of Japanese Art and Technology, with dr Jerzy Samusik and dr Zbigniew Jabłoński awarded the Jan of Ludzisk Medal - an award named after the great Polish $\mathrm{XV}^{\text {th }}$ century humanist and presented to the distinguished physician-writers, who - with their body of work and activity - propagate the values of humanism in medicine. 